\title{
Antioxidant effect of the pequi oil (Caryocar brasiliense) on the hepatic tissue of rats trained by exhaustive swimming exercises
}

\author{
A. F. Vale ${ }^{a}$, H. H. Ferreira ${ }^{a}$, E. J. Benetti ${ }^{a}$, A. C. S. Rebelo ${ }^{a}$, A. C. R. Figueiredo, \\ E. C. Barbosa ${ }^{a}$ and K. Simões ${ }^{a *}$ \\ a'Departamento de Morfologia, Instituto de Ciências Biológicas, Universidade Federal de Goiás - UFG, \\ Av. Esperança, s/n, Samambaia, CEP 74690-900, Goiânia, GO, Brasil \\ *e-mail:simoesk@ufg.br
}

Received: May 15, 2017 - Accepted: November 30, 2017 - Distributed: May 31, 2019

(With 5 figures)

\begin{abstract}
Increased oxygen consumption and activation of specific metabolic pathways during or after physical exercise lead to the formation of reactive oxygen and nitrogen species. An investigation was made into the effects of pequi oil supplementation in protecting liver cells against injury resulting from oxidative stress. The experiments involved 20 male adult Wistar rats (Rattus norvegicus). The animals were divided into four experimental groups: Group 1: sedentary control group; Group 2: exercise control group; Group 3: supplemented sedentary group; and Group 4: supplemented exercise group. Supplementation consisted of pequi oil administered by oral gavage (400 mg). The animals of the exercised groups were subjected to 20 swimming sessions for 5 weeks (with progressive increase of 10 minutes until exhaustion). Samples were collected from the right hepatic lobe for histopathological analysis and determination of malondialdehyde levels. The histopathological analyses revealed that the animals of the exercised control group had moderate liver damage, while the animals of the supplemented exercised group had slight tissue damage, and the sedentary control and sedentary supplemented groups showed no tissue damage. The malondialdehyde levels showed higher and statistically significant in exercise control group when compared to the other evaluated groups $(\mathrm{p}<0.05)$. In conclusion the supplementation with pequi oil had a protective effect on liver cells against damage caused by oxygen free radicals during strenuous exercise, as demonstrated by the indicator of lipid peroxidation.
\end{abstract}

Keywords: liver, antioxidant, exercise, oxidative stress.

\section{Efeito antioxidante do óleo de pequi (Caryocar brasiliense) no tecido hepático de ratos treinados por exercícios de natação exaustivos}

\begin{abstract}
Resumo
Aumento do consumo de oxigênio e ativação de vias metabólicas específicas durante ou após a atividade física conduz para formação de espécies reativas de oxigênio e nitrogênio. Uma investigação foi realizada sobre os efeitos da suplementação com óleo de pequi na proteção das células hepáticas contra lesões resultantes do estresse oxidativo. $\mathrm{Na}$ realização dos experimentos foram utilizados 20 ratos machos adultos da linhagem Wistar (Rattus novergicus). Os animais foram divididos em quatro grupos experimentais: grupo 1: grupo sedentário controle; grupo 2: grupo treinado controle; grupo 3: grupo sedentário suplementado e grupo 4: grupo treinado suplementado. Na suplementação foi utilizado o óleo de pequi ministrado por gavagem oral (400 mg). Os animais dos grupos treinados foram submetidos a 20 sessões de natação por um período de 5 semanas (com aumento progressivo de 10 minutos até a exaustão). Foram retiradas amostras do lobo hepático direito para análises histopatológicas, e dosagem de malondialdeído. As análises histopatológicas revelaram que os animais do grupo treinado controle tiveram danos hepáticos moderados; já os animais do grupo treinado suplementado tiveram danos teciduais leves; os grupos sedentário controle e sedentário suplementado não apresentaram injúrias teciduais. Os níveis de malondialdeído mostraram-se maiores e estatisticamente significativos no grupo treinado controle quando comparados aos outros grupos avaliados $(\mathrm{p}<0,05)$. Podemos concluir que a suplementação com óleo de pequi teve efeito protetor nas células hepáticas contra os danos causados pelos radicais livres de oxigênio durante os exercícios exaustivos, conforme demonstrado pelo indicador de peroxidação lipídica.
\end{abstract}

Palavras-chave: fígado, antioxidante, exercícios, estresse oxidativo. 


\section{Introduction}

Increased oxygen consumption and activation of specific metabolic pathways during or after physical exercise lead to the formation of reactive oxygen and nitrogen species (RONS). It is known that physical exercising leads to the intense production of RONS arising from the activation of metabolic pathways such as increased mitochondrial activity (Fisher-Wellman and Bloomer, 2009; Miranda-Vilela et al., 2016). These processes lead to high levels of RONS production because of the body's inability to balance its energy demand, causing an imbalance in these pathways and consequent metabolic damage.

When the body undergoes periods of metabolic overload, such as that occurring during strenuous exercise, it accumulates reactive oxygen species (ROS) in the liver tissue, which can trigger tissue damage ranging from slight degeneration to cirrhosis. In this regard, the liver is the organ most susceptible to the damaging effects of ROS, leading to numerous structural and functional injuries, which, despite its high regenerative capacity, can result in irreversible lesions (Araujo et al., 2013).

There are several ways to measure the amount of RONS produced in a given tissue, as well as the possible damage these molecules cause. An example is the quantification of products of lipid peroxidation. One of the products generated by the breakdown of lipid chains is a substance known as malondialdehyde (MDA), and high levels of this substance indicate an increase in membrane lesions caused by ROS (Bezerra et al., 2004).

Lesions caused by RONS in the liver cells can be prevented or reduced by the activity of antioxidants, which are present in many foods. Antioxidants can act directly to neutralize the effects of free radicals via direct bonds or participate indirectly in enzymatic systems, forming a metabolic barrier against the action of ROS and preventing them from causing severe damage to hepatic tissue (Shami and Moreira, 2004).

The exploitation of natural antioxidants has become increasingly important in recent years (Roesler et al., 2010). Pequi (Caryocar brasiliense) is a tree typical of the Brazilian cerrado, whose fruit is widely used in folk medicine. Pequi fruit pulp oil contains various carotenoids (Miranda-Vilela et al., 2009a). Studies have shown that the ethanol extract of this fruit has high total phenolic content and an excellent antioxidant activity via bioactive molecules (Miranda-Vilela et al., 2009a). Montalvão et al. (2016) studying the antioxidant effect of pequi oil in patients with systemic lupus erythematosus have shown a significant reduction of the inflammatory processes. However, no consistent data were found about the possible protective role of the antioxidants contained in pequi oil during strenuous exercise, in terms of maintaining the morphological integrity of liver cells, justifying our study.

\section{Material and Methods}

The experiments involved 20 male adult Wistar rats (Rattus norvegicus), weighing from 200 to $250 \mathrm{~g}$, which were supplied by the vivarium of the Federal University of
Goiás (UFG). The animals were housed in plastic cages, each containing five animals, in a room climatized to an average temperature of $22^{\circ} \mathrm{C}$. The animals were subjected to a natural photoperiod with water and feed ad libitum and were divided into four experimental groups with 5 animals: G1) sedentary control group; G2) exercise control group; G3) sedentary group supplemented with pequi oil; G4) exercise group supplemented with pequi oil.

Supplementation consisted of $400 \mathrm{mg}$ of pequi oil extracted from the fruit pulp, administered via gavage through a gastric tube, 5 times a week, for 4 weeks. The daily intake of pequi oil was calculated based on the maximum dose of vitamin A precursor carotenoids recommended (Miranda-Vilela et al., 2009a). The project was approved by the Ethics Committee on Animal Use of UFG (CEUA-UFG, Process No. 024/11).

\subsection{Preparation of pequi oil}

Pequi fruit (Caryocar brasiliense) were obtained directly from producers in the region of Goiânia. After removing the rind, the pulp was subjected to extraction by cold maceration to obtain pequi oil, using ethanol as solvent. The resulting extract was subjected to low pressure evaporation at $40^{\circ} \mathrm{C}$ in a rotary evaporator, followed by vacuum drying, from which the oil was extracted and stored in a freezer in the dark.

\subsection{Exercise protocol}

The animals of the exercise groups (G2 and G4) were subjected to 20 swimming sessions over a period of four weeks, Mondays to Fridays, between $1 \mathrm{pm}$ and 5:30 pm, in two tanks containing water at $30^{\circ} \mathrm{C}$. The training program consisted of daily swimming sessions, five days per week (Garcia et al., 2010). In the first week, to adapt them to the exercise, the animals swam for 10,20,30,40, and 50 minutes a day. In the second week they swam for 50 minutes (Monday and Tuesday) and for 60 minutes (Wednesday to Friday). Starting from the third week, the animals swam until they reached physical exhaustion. They were then euthanized three hours after the last swimming session, via saturation anesthesia with an intraperitoneal injection of pentobarbital $(20 \mathrm{mg} / 100 \mathrm{~g}$ body weight).

\subsection{Histopathological analysis}

Fragments were removed from the right hepatic lobe and fixed in $10 \%$ formaldehyde solution. The tissues were embedded in Paraplast Plus (Sigma) and Historesin (Leica). Histological sections $(3 \mu \mathrm{m})$ were stained with Hematoxylin-Eosin and Hematoxylin-Phloxine. The slides were analyzed and photo-documented using a light photomicroscope (Leica DM3000).

\subsection{MDA levels}

Liver homogenate from the animals was used to determine malondialdehyde levels, using a TBARS Assay Kit (Cayman Chemical Company, USA). The supernatant was analyzed in a spectrophotometer at $550 \mathrm{~nm}$ and expressed in $\mathrm{nmol} / \mathrm{mL}$. 


\subsection{Statistical analysis}

IBM SPSS Statistics software (version 21) was used for the statistical analyses. The MDA levels were compared by analysis of variance (ANOVA) and their means were tested by Tukey's test, at a 5\% significance level. The data were expressed as means and standard deviation.

\section{Results}

Three major groups of pathological changes were selected and evaluated individually in the histopathology analysis: hydropic degeneration, fatty degeneration, and presence of lymphocytic infiltrate, which served as indicators of liver damage.

The animals of the control group (G1) presented normal morphological aspects with maintenance of the cell structure, sinusoids, hepatocytes and Kupffer cells. Focal regions were found containing lymphocytic infiltration, hydropic degeneration and fatty degeneration (Figure 1).

The animals of the non-supplemented exercise group (G2) presented altered histopathological aspects, with cells showing moderate hydropic degeneration and moderate fatty degeneration, as well as mild lymphocytic infiltration (Figure 2).

The animals of the supplemented sedentary group (G3) showed unchanged histopathological aspects, such as maintenance of the cellular structure, preserved sinusoids, intact Kupffer cells, hepatocytes, and preserved blood vessels and ducts (Figure 3 ).

The animals of the supplemented exercise group (G4) presented normal histopathological aspects, with maintenance of the cell structure, preserved sinusoids, hepatocytes and Kupffer cells. Focal regions were found containing hydropic degeneration and fatty degeneration (Figure 4).

As for thiobarbituric acid-reactive substances in rat liver tissue, a comparison of groups G1 $(0.30 \pm 0.05)$ and G3 (0.30 \pm 0.03$)$; $\mathrm{G} 1$ and G4 $(0.35 \pm 0.55)$; and G3 and G4 showed no statistically significant differences. However, higher and statistically significant values were found for $\mathrm{G} 2(0.62 \pm 0.35)$ when compared to the other groups under study $(\mathrm{p}<0.05)$, indicating oxidative stress (Figure 5).

\section{Discussion}

During the performance of strenuous exercise, various substances are produced by the metabolic process, such as reactive oxygen species (ROS). Excessive amounts of ROS are potentially harmful to the body if they are not quickly neutralized and eliminated. These substances appear as an organic response to intense physical activity (Fisher-Wellman and Bloomer, 2009).
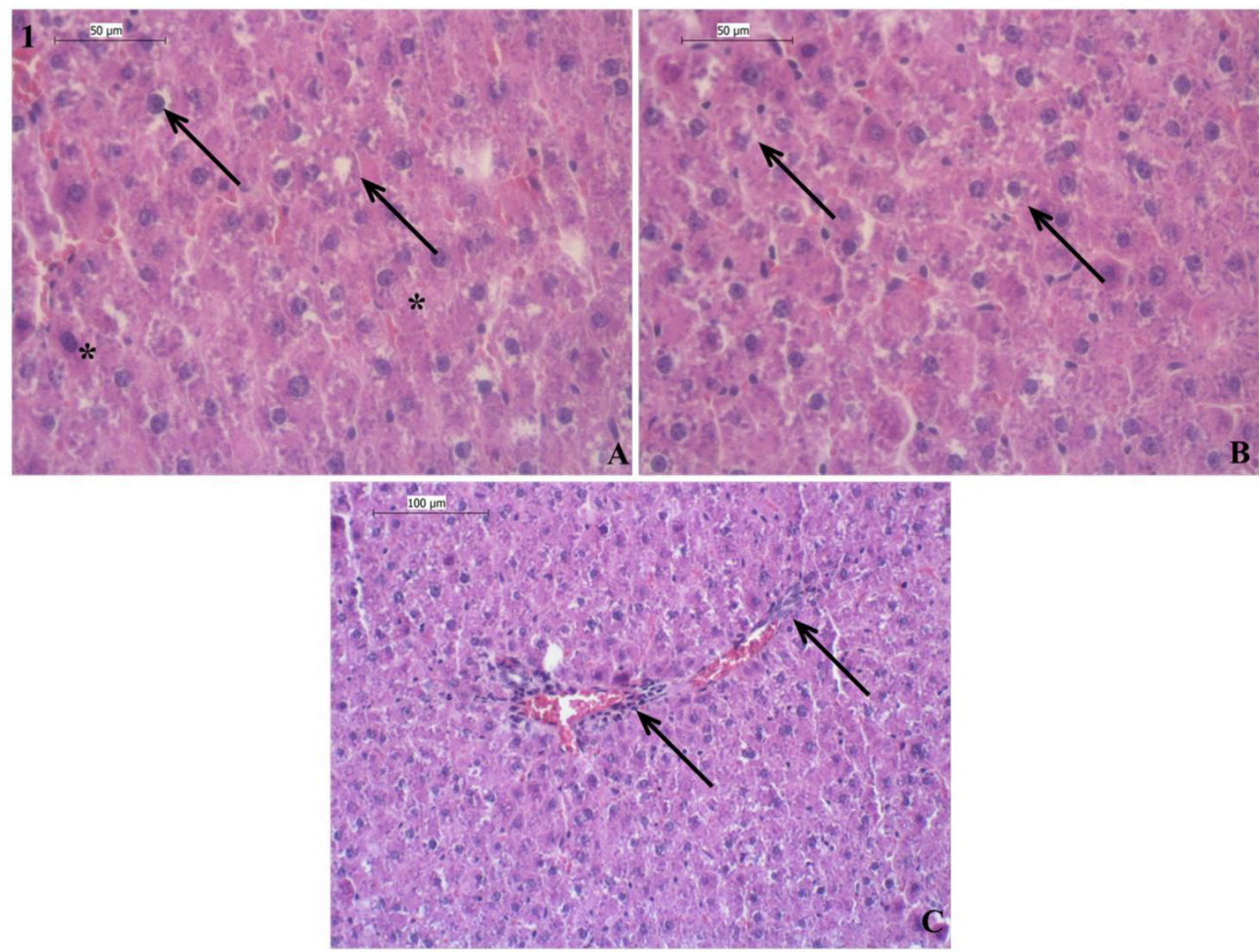

Figure 1. Cross section of the right lobe of a rat of G1.A, B) Presence of intact hepatocytes $(*)$ and cells in fatty degeneratin $(\rightarrow)$, scale bar $=50 \mu \mathrm{m}$. C) Intact hepatocytes and lymphocytic infiltrate surrounding the vessel $(\rightarrow)$, scale bar $=100 \mu \mathrm{m}$. 

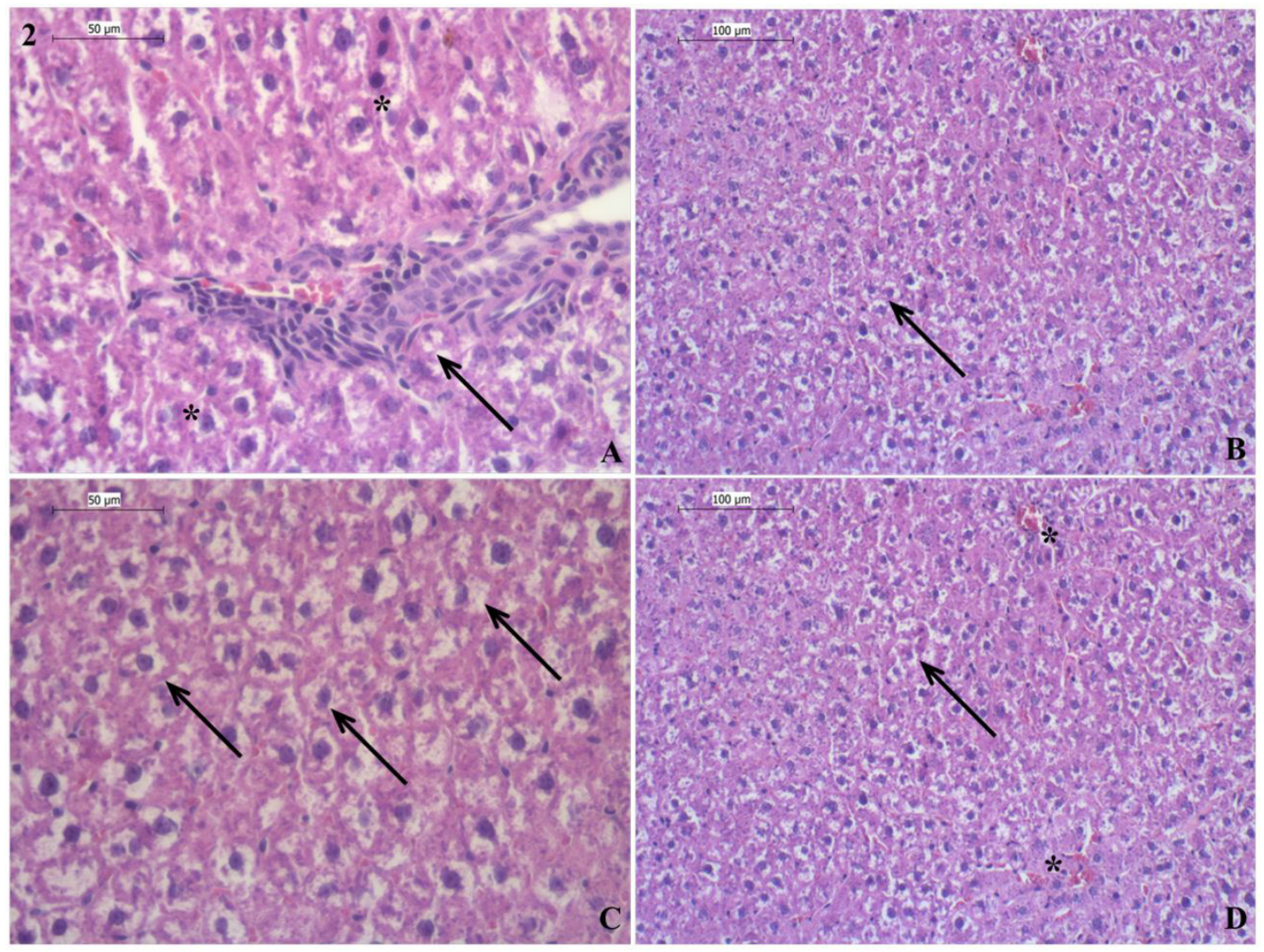

Figure 2. Cross section of the right lobe of a rat of G2. A) Cells in hydropic degeneration $(*)$ and lymphocytic infiltrate $(\rightarrow)$, scale bar $=50 \mu \mathrm{m}$. B) Cells in fatty degeneration $(\rightarrow)$, scale bar $=100 \mu \mathrm{m}$. C) Cells in fatty degeneration $(\rightarrow)$, scale bar $=50 \mu \mathrm{m}$. D) Presence of cells in hydropic degeneration $(\rightarrow)$ and blood vessels $(*)$, scale bar $=100 \mu \mathrm{m}$.
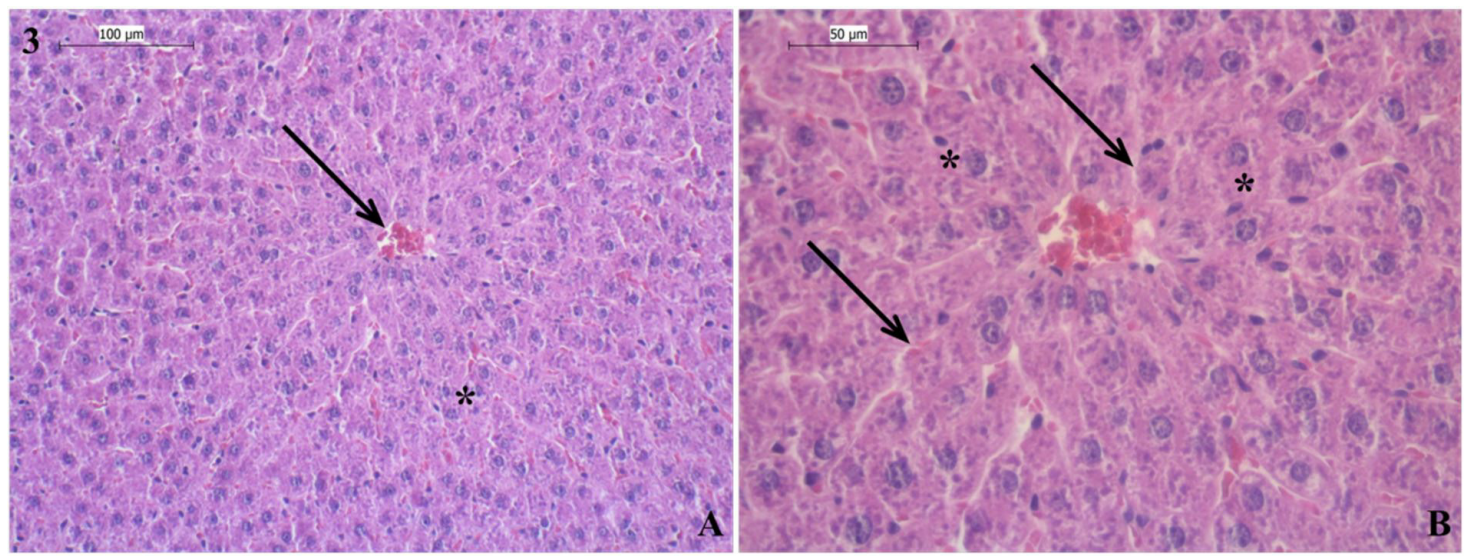

Figure 3. Cross section of the right lobe of a rat of G3. A) Intact hepatocytes $(*)$ and preserved blood vessel $(\rightarrow)$, scale bar $=100 \mu \mathrm{m}$. B) Hepatocytes $(*)$ and preserved sinusoids $(\rightarrow)$, scale bar $=50 \mu \mathrm{m}$.

The excessive formation of ROS is considered harmful to the organism because they are molecules that can cause irreversible cell damage, such as destruction of the cell membrane, permanent binding to functional proteins, and permanent interaction with DNA, among others, which may lead to destructuring of various types of tissues. High performance athletes are major victims of the oxidative stress caused by ROS, such as premature aging, muscle lesions, heart problems, and particularly liver damage (Araujo et al., 2013). 

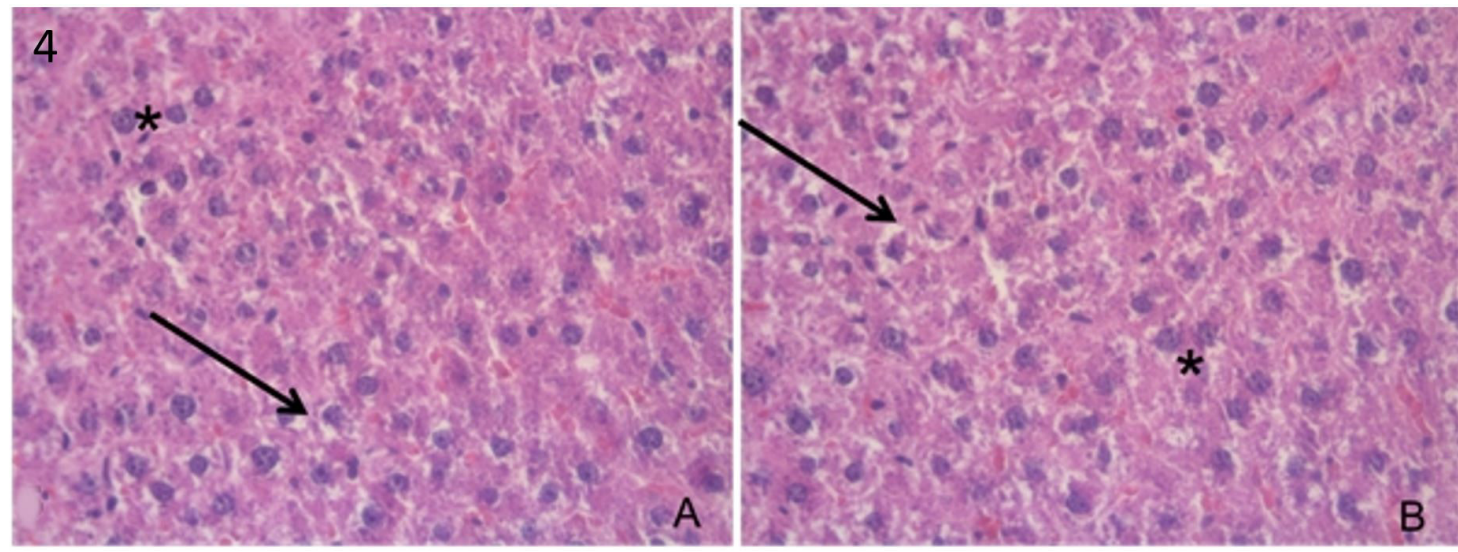

Figure 4. Cross section of the right lobe of a rat of G4. A) Intact hepatocytes $(*)$ and cells in hydropic degeneration $(\rightarrow)$, scale bar $=50 \mu \mathrm{m}$. B) Hepatocytes $(*)$ and cells in fatty degeneration $(\rightarrow)$, scale bar $=50 \mu \mathrm{m}$.

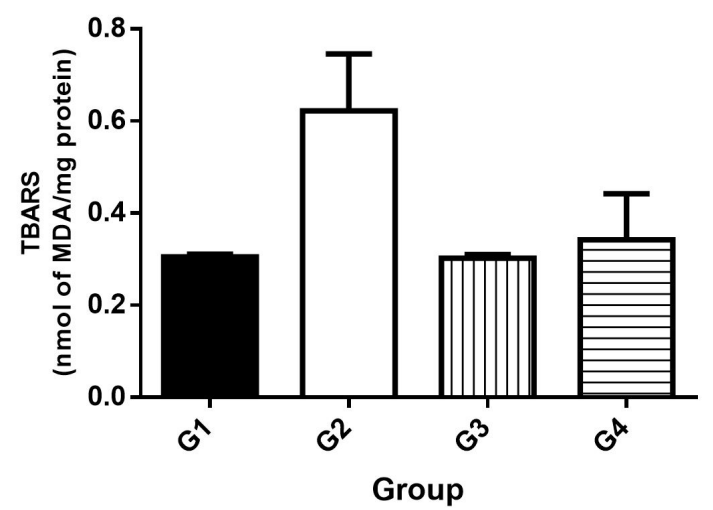

Figure 5. Thiobarbituric acid-reactive substances in rat liver tissue. G1: control group; G2: non-supplemented exercise group; G3: sedentary supplemented group; G4: supplemented exercise group. Level of significance $\mathrm{p}<0.05$.

There are several possible ways to counteract the effects of ROS, the most common one being the use of antioxidants. Currently, a variety of substances can be considered antioxidants and they are already well elucidated in the literature (Simões et al., 2014). However, these substances are still relatively expensive in purified form, and obtaining them from food is limited when compared to the amount of ROS produced during strenuous exercise (El-Saad et al., 2016).

In this study, we chose to test the antioxidant activity of pequi oil because this fruit has various types of antioxidants and is used in the production of skin creams and moisturizing lotions, as a cicatrizer in the Brazil (Miranda-Vilela et al., 2009b).

The histopathological analysis of the animals of the exercise group (G2) revealed moderate tissue damage, such as hydropic and fatty degeneration, in addition to lymphocytic infiltration. Such damage indicates that the tissue in question underwent injuries caused by the action of ROS, which was confirmed by the malondialdehyde levels. This fact also proves that the exercise protocol was effective in inducing the production of ROS. The animals of the supplemented exercise group (G4) showed only mild tissue damage, indicating the antioxidant potential of supplementation with pequi oil.

The animals of the sedentary control and supplemented groups (G1 and G3) showed no significant morphological damage, proving that the tissue damage in the other groups was caused by strenuous exercise and the production of ROS. It is worth mentioning that the sedentary group (G1) showed no focal lesions and was the most morphologically preserved group. It can therefore be inferred that the pequi oil acted as an antioxidant, reducing tissue damage caused by free radicals during strenuous exercise, acting as a hepatic protector, forming a barrier against other harmful metabolic processes such as necrosis, fibrosis, steatosis and cirrhosis, similar to what Miranda-Vilela et al. (2014) found in patients in a condition of oxidative stress.

Malondialdehyde was used as a biomarker of free radicals to characterize oxidative stress at the cellular level (Hashem et al., 2015). The findings confirmed that supplementation with pequi oil was effective in protecting the liver against damage caused by free radicals, since the supplemented exercise, sedentary and control groups showed no statistically significant difference, unlike the non-supplemented exercise group (G2), which showed a value of $p<0.5$ compared to the others, indicating cell damage in this group.

Miranda-Vilela et al. (2014) demonstrated that pequi oil was able to dramatically reduce the effects of ROS on hepatic cells. As their experimental model they used chemotherapeutic drugs, which cause increased oxidative stress in the liver and consequent accumulation of free radicals, and supplementation with pequi oil. Their results demonstrated that this supplementation had a protective and antioxidant effect on the liver cells, even in the group subjected to chemotherapeutic drugs, indicating the versatility of supplementation with pequi oil, which can 
act in the diet of professional athletes as well as in that of cancer patients.

An analysis of the results of this study revealed that supplementation with pequi oil has a protective effect on the liver tissue against injuries caused by ROS, when comparing the non-supplemented exercise and supplemented exercise groups, and that pequi oil can be successfully used as an antioxidant and liver protector. In conclusion the supplementation with pequi oil has a protective effect on liver cells against damage caused by oxygen free radicals during strenuous exercise.

\section{Acknowledgements}

The authors thank the Fundação de Amparo à Pesquisa do Estado de Goiás (FAPEG, Proc. N 201210267001073) for the financial support.

\section{References}

ARAÚJO, M.B., MOURA, L.P., VIEIRA-JUNIOR, R.C., COSTA JUNIOR, M., DALIA, R.A., SPONTON, A.C., RIBEIRO, C. and MELLO, M.A., 2013. Creatine supplementation and oxidative stress in rat liver. Journal of the International Society of Sports Nutrition, vol. 10, no. 1, pp. 54-62. http://dx.doi.org/10.1186/15502783-10-54. PMid:24325803.

BEZERRA, F.J.L., REZENDE, A.A., RODRIGUES, S.J. and ALMEIDA, M.G., 2004. Determinação das substâncias reativas ao ácido tiobarbitúrico como indicador da peroxidação lipídica em ratos tratados com sevoflurano. Revista Brasileira de Anestesiologia, vol. 54, no. 1, pp. 1640-1649.

EL-SAAD, A.A., IBRAHIM, M.M., HAZANI, A.A. and ELGAALY, G.A., 2016. Lycopene attenuates dichlorvos-induced oxidative damage and hepatotoxicity in rats. Human and Experimental Toxicology, vol. 35, no. 6, pp. 654-665. http://dx.doi. org/10.1177/0960327115597981. PMid:26231422.

FISHER-WELLMAN, K. and BLOOMER, R.J., 2009. Acute exercise and oxidative stress: a 30 year history. Dynamic Medicine, vol. 8, no. 1, pp. 1-25. http://dx.doi.org/10.1186/1476-5918-8-1. PMid:19144121.

GARCIA, B.C., CAMARGO-FILHO, J.C.S., VANDERLEI, L.C.M., PASTRE, C.M., CAMARGO, R.C.T., SOUZA, T.A., HAIDAMUS, L.L. and OLIVEIRA, A.C., 2010. Efeitos da dieta suplementada com ômega-3 no músculo sóleo de ratos submetidos à natação: análise histológica e morfométrica. Revista Brasileira de Medicina do Esporte, vol. 16, no. 1, pp. 363-367. http://dx.doi. org/10.1590/S1517-86922010000500009.

HASHEM, R.M., RASHD, L.A., HASHEM, K.S. and SOLIMAN, H.M., 2015. Cerium oxide nanoparticles alleviate oxidative stress and decreases Nrf-2/HO-1 in D-GALN/LPS induced hepatotoxicity. Biomedicine and Pharmacotherapy, vol. 73, pp. 80-86. http:// dx.doi.org/10.1016/j.biopha.2015.05.006. PMid:26211586.
MIRANDA-VILELA, A.L., AKIMOTO, A.K., ALVES, P.C.Z., PEREIRA, L.C.S., GONALVES, C.A., KLAUTAU-GUIMARES, M.N. and GRISOLIA, C.K., 2009a. Dietary carotenoid-rich pequi oil reduces plasma lipid peroxidation and DNA damage in runners and evidence for an association with MnSOD genetic variant -Va19Ala. Genetics and Molecular Research, vol. 8, no. 4, pp. 1481-1495. http://dx.doi.org/10.4238/vol8-4gmr684. PMid:20082261

MIRANDA-VILELA, A.L., GRISOLIA, C.K., LONGO, J.P.F., PEIXOTO, R.C.A., ALMEIDA, M.C., BARBOSA, L.C.P., ROLL, M.M., PORTILHO, F.A., ESTEVANATO, L.L.C., BOCCA, A.L., BÁO, S.N. and LACAVA, Z.G.M., 2014. Oil rich in carotenoids instead of vitamins $\mathrm{C}$ and $\mathrm{E}$ as a better option to reduce doxorubicin-induced damage to normal cells of Ehrlich tumor-bearing mice: hematological, toxicological and histopathological evaluations. The Journal of Nutritional Biochemistry, vol. 25, no. 11, pp. 1161-1176. http://dx.doi. org/10.1016/j.jnutbio.2014.06.005. PMid:25127291.

MIRANDA-VILELA, A.L., PEREIRA, L.C.S., GONÇALVES, C.A. and GRISOLIA, C.K., 2009b. Pequi fruit (Caryocar brasiliense Camb.) pulp oil reduces exercise-induced inflammatory markers and blood pressure of male and female runners. Nutrition Research (New York, N.Y.), vol. 29, no. 12, pp. 850-858. http:// dx.doi.org/10.1016/j.nutres.2009.10.022. PMid:19963158.

MIRANDA-VILELA, A.L., RIBEIRO, I.F. and GRISOLIA, C.K., 2016. Association between interleukin $6-174 \mathrm{G} / \mathrm{C}$ promoter gene polymorphism and runners' responses to the dietary ingestion of antioxidant supplementation based on pequi (Caryocar brasiliense Camb.) oil: a before-after study. Genetics and Molecular Biology, vol. 39, no. 4, pp. 554-566. http://dx.doi.org/10.1590/1678-4685gmb-2015-0299. PMid:27727360.

MONTALVÃO, T.M., MIRANDA-VILELA, A.L., GRISOLIA, C.K. and SANTOS-NETO, L.L., 2016. Anti-inflammatory Effect of Antioxidant Pequi (Caryocar brasiliense) Oil Capsules and Antioxidant Effect of Vitamin D and Physical Activity on Systemic Lupus Erythematosus Patients. Journal of Rheumatic Diseases and Treatment, vol. 2, no. 1, pp. 1-7. http://dx.doi. org/10.23937/2469-5726/1510029.

ROESLER, R., LORENCINI, M. and PASTORE, G., 2010. Brazilian cerrado antioxidant sources: cytotoxicity and phototoxicity in vitro. Food Science and Technology (Campinas), vol. 30, no. 1, pp. 814-821. http://dx.doi.org/10.1590/S0101-20612010000300038.

SHAMI, N.J.I.E. and MOREIRA, E.A.M., 2004. Licopeno como agente antioxidante. Revista de Nutrição, vol. 17, no. 1, pp. 227-236. http://dx.doi.org/10.1590/S1415-52732004000200009.

SIMÕES, K., MAGOSSO, R.F., LAGOEIRO, C.G., CASTELLAN, V.T., SILVA, N.S., SCRIVANTE, B.F., QUALHATO, G., FIGUEIREDO, A.C.R., BENETTI, E.J. and REBELO, A.C.S., 2014. Ação do licopeno nos músculos esquelético e cardíaco sob estresse oxidativo por exercícios. Revista Brasileira de Medicina do Esporte, vol. 20, no. 1, pp. 105-109. http://dx.doi. org/10.1590/1517-86922014200201518. 